二勤カス。

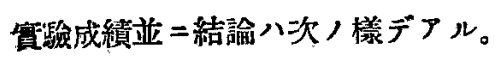

（1）蛙體 7 蛙板二固定シテ. 左右蝴/周り =迴轉スルト.頭下位デハ淋巴心ノ搏動八停止. 減少及ハ不規則性习起ス。頭上位デハ之二反シ テ却ッテ增加又ハ其倾向フ是スル。但シ背位デ 八著明八變化入認メラレナ1。

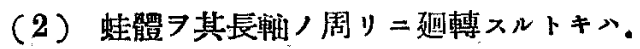
前記ノナウナ搏動ノ變化八兄ル事が出隶ナイ。

（3）斯カル變化，原因八血心ニハ存シナ 1。血心ノ搏動ハ前通淋巴心ノ搏動 リリ速デア ル外ニ、體位ノ變動ニヨッテモ殆ント影響サレ +1 。

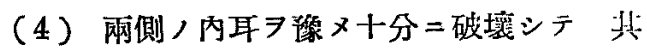
機能 $尹$ 監クシテテクト上記，搏動變化八消失ス

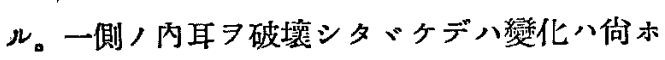
碊存スルケレドモ，其程度が輕クナル。

(5) 耳石习露出シテえア人工的=動カシテ 見ルト，上ト全ク同樣，變化ヨ起スコトガ出棑 ル。郎チ耳石 7 上方二抑スト，淋巴心，搏動八 停止シタリ，減少シタリ，不規則ニナツタリス ル。又耳石ヨ下方二押スト搏動八堆加スル。最 後=耳石ヨ右又ハ左=押シテモ搏動ハ影響 ヨ受 ケナイ。

(6) 要スル二余/見出シタ澧位ノ變勳 $=\exists$ ル淋巴心搏動/變化八 其原因ガ内耳ニアリト シテ說明ガ出爽ルト思フ。

\section{5. 耳畾咽喉科垁患小血小板}

後藤 末 男(東北大) スペテアラュル疾患=於テ 其血液瀿所見 知ルハ. 診斷及ビ像後制定上. 不可缺，事トナ ツタ。而シテ．赤血球．白血球又八赤血球沈降 速度等ハ日常盛二用ヒラレ應用セラレッア
ル。然ル二，前者同樣血液习榡成ス儿分子ノ一 ッデアル血小板八，2-3 特異ナル疾㭧习除 テハ，沿ンド检查サレテキナイ，てナラズ其 正常値スラ區タタルモノデアル。此血小板ノ性 留が破塆シ易ク㠜集シ易イトイフ然エアルガ。

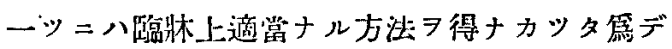
アル。

現在マデ最モ多ク用ヒラレタ方法ハFonio， 法デアッタガ. 1931 年 Lampert =依ッテ

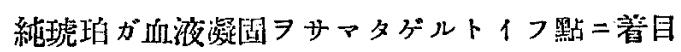
シ 血小板测定用トシテ純琥帕製「ピペット」

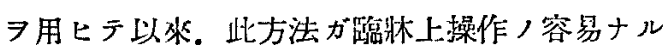

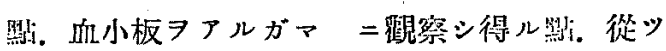
テ血小板ノ大小形狀等 7 容易 $=$ 知り得儿照等 $\exists$ リシテ次第二用ヒラレッアル。

余モ亦.耳鼠咽喉科涋㭧二於亏血小板，計量的 研究ノ殆ンド見賞ラナイノ=壏ミ。 Lampert， 方法二依シテ 種タナル疾患二於ケル血小板 测定セルラ以テ 其大略フ報告シ参考二供セン トスルモノデアル。

血液稀釋溶液トシテハ Tyrode 液 7 用七。Athrombit =テ 200 倍二稀釋スル。探血部位八

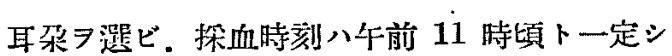
夕。計华八Thoma-Zeiss, 血球計算器 タ。

血小板ノ大小八大體 3 型二區别シ。大キサ略に 赤血球卜等シキモ，第 1 型. 赤血球，約牛分乃 至 $1 / 4$ ナルモノ第 2 型. 夫レ以下，微小形二第 3 型トシタ。

以下. 其测定結果习表示スルニ次ノ如シ（單= 平均數ノミラ示シタ)。(單位八藏) 


\begin{tabular}{|c|c|c|c|c|c|}
\hline 疤荫 & 例数 & 第一型 & 第二型 & 第三型 & 總計 \\
\hline 急性中耳炎 & 8 & 0.38 & 22.64 & 39.25 & 62.25 \\
\hline 慢性中耳炎 & 9 & 0.56 & 17.28 & 42.11 & 59.94 \\
\hline 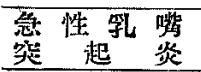 & 13 & 0.23 & 28.81 & 47.67 & 77.50 \\
\hline 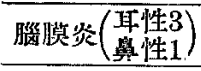 & 4 & 0.75 & 15.25 & 28.87 & 44.87 \\
\hline 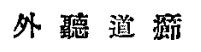 & 5 & 0.33 & 27.33 & 33.0 & 60.66 \\
\hline 慢性副舅舼炎 & 16 & 0.34 & 15.47 & 34.0 & 49.81 \\
\hline 龩 & 4 & 1.0 & 23.0 & 32.0 & 56.0 \\
\hline 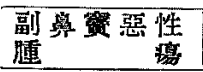 & 5 & 2.8 & 24.6 & 68.2 & 95.6 \\
\hline 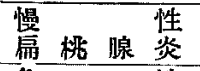 & 5 & 1.33 & 24.0 & 34.0 & 59.33 \\
\hline 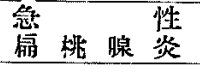 & 5 & 0.4 & 19.9 & 37.7 & 58.0 \\
\hline 急性咽喉頙资 & 4 & 0.66 & 22.33 & 36.83 & .59 .83 \\
\hline 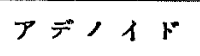 & 4 & 1.12 & 23.37 & 38.37 & 62.87 \\
\hline 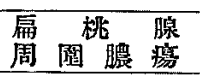 & 3 & 1.33 & 27.0 & 40.67 & 69.0 \\
\hline 喉 頭 癌 & 3 & 0.66 & 23.66 & 50.0 & 74.33 \\
\hline 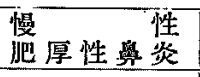 & 3 & 0.5 & 26.33 & 43.0 & 69.83 \\
\hline 㓩溲性悬炎 & 4 & 0.5 & 17.37 & 38.12 & 55.75 \\
\hline 正 労 人 & 20 & 0.7 & 19.8 & 42.45 & 62.95 \\
\hline
\end{tabular}

即チ，耳疾㭧中．中耳炎＝於テハ略を，正常值 ト同檬デアルガ. 乳嘴突起炎二於テハ血小板ハ 增加ス。而シテ第 2 型二於テ甚ダシ。畠膜炎= 於テハ逆二減小ス。鼻疾患二於テ慢性ノ蓄膿症 二於テ八稍 3 減少ス。惡性腫瘍二於テ八选ダシ ク增加ス。第 3 型二於亏殊二然り。尚木第 1 型 モ增加ス。扇桃腺疾腎二於テ八大體正常值中二 アルモ. 2-3 第 1 型ノ稍 2 燴加スルガ如シ。 倘示余八耳性敗血症其他 2-3，疾患八例數不 足ノ䉆メ報告シ得ナカッタガ. 更二次回終報卜 シデ完全ヨ期サウト思ツテキル。

\section{類題 耳疾患二於々ル血小板}

消長卜其診斷的價值二就テ

筑 紫 檾一(東 京)
血小板ガ血液，第 3 要素トシテ重要ナコトハ 諸賢ノ御承知ノ事デアリ 之ガ检索习行ヒ。抙

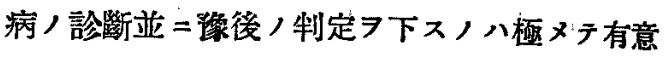
䉝ノ事卜思ヒマス。私八耳疾患コト＝中耳疾㭧 及ビ其合係症ニシキ此检查ヨ行ヒアシタノデ其

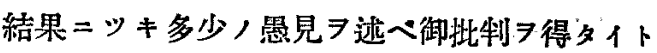
思ヒマス。

血小板检查八其性質上從來八カナり困難トサ レ.箎二種タノ檢查方法ガ考案サレテ居マスガ.

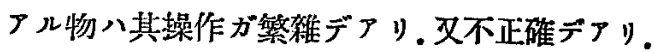
或物八設借 $=$ 費用 7 要ス几篇入實際=臨牃的 $=$ 之ラ應用スルニ不便フ感ジタノデアリマス。私 八此點カラ松岡一川畑氏法ガ適當デアルト考へ マシタノデ本法ア探用致シマシタ。简單 =其方

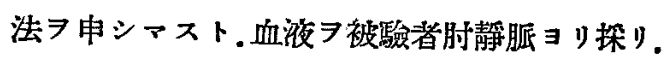
同時 $=$ 之 7 血液凝固防止劑夕ル第 1 液卜混和稀 釋シ. 之ヨ赤血球算定用「ピベット」=吸引.

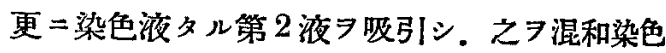
シ一定時啳=血球計算室 =封入計算スルノデヌ リマス。

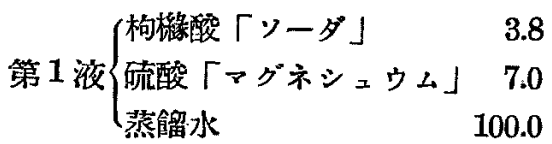

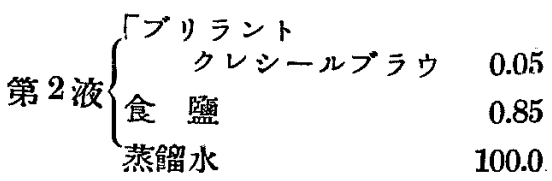

デアリマス。

私ハ先ヅ 10 名ノ健康者ニッキ检查政シャシタ (表示)。

向木諸家ノ算出シマシタ正常血小板ト併七考へ マスト大體 30 萭前後ヨ以テ正常ト見テョイ ト思ヒマス。

次ニ私ノ检查シタ處ノ結果ニッキ說明致シャ 